\title{
Miocene to Pleistocene clay mineral sedimentation on the New Jersey shelf
}

\section{Patricia VANDERAVEROET *}

Sédimentologie et géodynamique, UMR 8577 CNRS, SN5, université de Lille-I, 59655 Villeneuve d'Ascq cedex, France

Received 20 April 1999; revised 13 October 1999; accepted 20 October 1999

\begin{abstract}
The clay fraction of sediments drilled at Ocean Drilling Program (ODP) sites 1071 and 1072 is composed of variable proportions of chlorite, illite, smectite, kaolinite, vermiculite and mixed-layers such as illite/vermiculite $(\mathrm{I} / \mathrm{V})$ and chlorite/vermiculite $(\mathrm{C} / \mathrm{V})$. Miocene and Pliocene climates allowed formation of vermiculite and kaolinite. Pleistocene clay sedimentation was characterized by abundant chlorite and illite resulting from increasing erosion of the crystalline rocks outcropping in northern areas (e.g. Canadian Shield) developed under glacial climate. The clay minerals identified on the shelf are relatively similar to those deposited on the New Jersey continental slope and rise, and a similar trend in the composition of clay assemblages is observed in the three depositional environments from Miocene to Pleistocene. The clay succession expresses the progressive lessening of hydrolyzing climates associated with increased physical weathering. (C) 2000 Ifremer/ CNRS/IRD/Éditions scientifiques et médicales Elsevier SAS
\end{abstract}

shelf / New Jersey / clay minerals / Neogene / palaeoclimate

Résumé - Sédimentation argileuse miocène à pléistocène sur la plate-forme du New Jersey. La fraction argileuse des sédiments forés aux sites ODP 1071 et 1072 est composée de chlorite, d'illite, de smectite, de kaolinite, de vermiculite et de minéraux interstratifiés tels que des illite/vermiculite $(\mathrm{I} / \mathrm{V})$ et des chlorite/vermiculite $(\mathrm{C} / \mathrm{V})$. La sédimentation argileuse au cours du Pléistocene était caractérisée par des proportions importantes de chlorite et d'illite en relation avec l'accroissement de l'érosion, sous climat glaciaire, des roches cristallines affleurant dans les régions septentrionales (par exemple Bouclier Canadien). Les minéraux argileux mis en évidence sur la plate-forme sont semblables à ceux observés dans les sédiments déposés sur la pente et le glacis au large du New Jersey. De plus, la composition des assemblages argileux montre une évolution similaire dans les trois environnements de dépôt du Miocène au Pléistocène. L'évolution du cortège argileux reflète l'accroissement de l'altération physique associé à la diminution progressive des climats hydrolysants. (C) 2000 Ifremer/CNRS/IRD/ Éditions scientifiques et médicales Elsevier SAS

plate-forme / New Jersey / minéraux argileux / Néogène / paléoclimat

\section{INTRODUCTION}

\subsection{Geological background and bathymetry of the outer New Jersey Shelf}

* Correspondence and reprints:

The US Atlantic border is a passive continental marpatricia.vanderaveroet@univ-lille1.fr gin with a tectonic history that has been dominated

(C) 2000 Ifremer/CNRS/IRD/Éditions scientifiques et médicales Elsevier SAS 
by thermal subsidence, sediment loading and flexure [35]. Rifting began in the Late Triassic [18] and seafloor spreading had begun by the Middle Jurassic ( $165 \mathrm{Ma})$ [46].

From the Oligocene to Miocene, siliciclastic sedimentation dominated offshore New Jersey [37]. The sediments progressively prograded seaward and formed well-developed upper Oligocene to Recent clinoforms which represent sequence boundaries. A series of thick sediment wedges built seaward during Miocene to produce a shelf with a terraced morphology. During glacial intervals in the Pleistocene, the lowering of sea-level caused the exposure of much of the continental shelf [35].

The New Jersey shelf break varies in depth from about $100 \mathrm{~m}$ in the south to more than $130 \mathrm{~m}$ in the north. The greater depth off northern New Jersey reflects the presence of a plateau-like feature in $100-$ $150 \mathrm{~m}$ water-depth between Hudson and Toms Canyons (figure 1). In addition to Hudson and Wilmington canyons at least seven other canyons are noted, the largest of which is Toms Canyon [31].

\subsection{Objectives of Leg $174 \mathrm{~A}$}

To evaluate the effects of 'Icehouse' glacioeustatic change on a passive continental margin characterized by predominantly siliciclastic sedimentation, the New Jersey Mid-Atlantic Sea-Level Transect (MAT) was

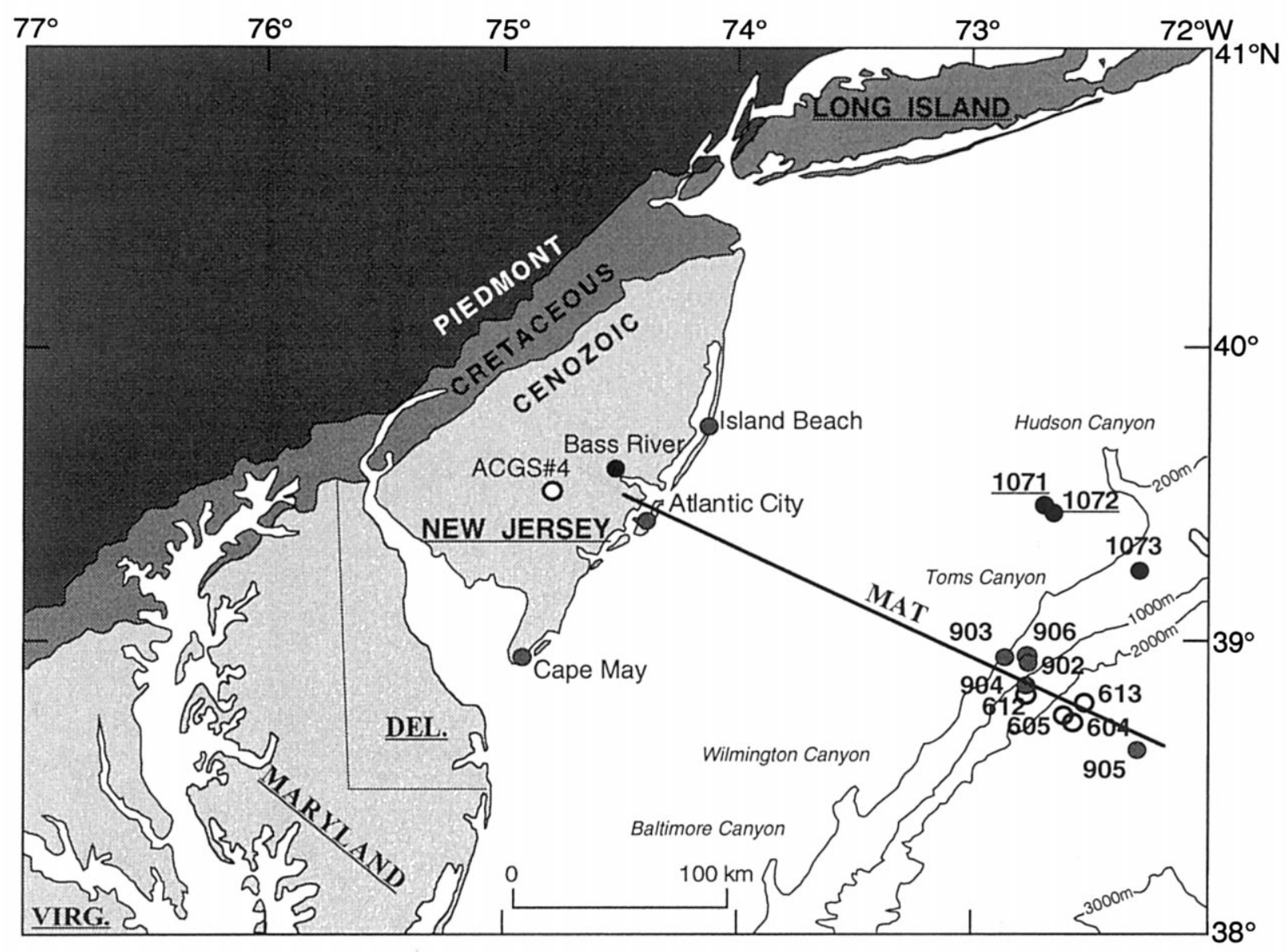

ODP Legs 174 and 174X ODP Legs 150 and 150X $\bigcirc$ previous drilled sites

Figure 1. Location of ODP sites drilled during Legs ODP 150, 150X, 174A, and 174X. 
created by the Sea Level Working Group (USA). The research program involved drilling into the slope, shelf, and coastal plain. The New Jersey slope and rise were drilled during Leg 150 [35]. Onshore drilling (Legs 150X and 174X) supplied updip facies control at multiple locations $[27,29,30]$. Leg 174A represents a continuation of the MAT with drilling of the New Jersey shelf.

The main objectives were to date as precisely as possible major Oligocene to Recent sequence boundaries and to evaluate their correlations to glacioeustatic estimates obtained from the $\delta^{18} \mathrm{O}$ record, to place constraints on the amplitudes and rates of sea-level change responsible for unconformity development, and to assess the relationships between depositional facies and sequence architecture. An additional goal for Leg 174A was technical because this Leg represented the first attempt by scientific ocean drilling in almost 30 years to sample a thicklysedimented continental margin in water depths $<150$ $\mathrm{m}[2]$.

The aim of this paper is to document variations in the nature and composition of clay mineral assemblages brought from the North American continent to the New Jersey shelf, and to identify environmental changes from Middle Miocene to Pleistocene, especially at Site 1072 where the recovery is better.

\subsection{Site location}

Sites 1071 and 1072 were drilled during Leg 174A on the New Jersey continental shelf (figure 1) [2]:

- Site 1071 is located at a water depth of $88-90 \mathrm{~m}$, at $\sim 130 \mathrm{~km}$ east of Atlantic City and $\sim 40 \mathrm{~km}$ north of Leg 150 Sites $902-904$ and 906 on the continental slope. Its position is $39^{\circ} 22^{\prime} \mathrm{N}, 72^{\circ} 43^{\prime} \mathrm{W}$.

- Site 1072 is located at a water depth of $98 \mathrm{~m}$, at $\sim 3.5 \mathrm{~km}$ seaward of Site 1071. Its position is $39^{\circ} 21^{\prime}$ $\mathrm{N}, 72^{\circ} 41^{\prime} \mathrm{W}$.

\subsection{Lithostratigraphy and biostratigraphy}

Sand is abundant down to $400 \mathrm{mbsf}$, which created significant problems for hole stability during both coring and logging operations. Core recovery was only $32.2 \%$ for shelf sites, with best recovery in clay-rich sediments and poorest recovery in unconsolidated quartz sand [2].

Preliminary age assignments were established using core-catcher samples. Three microfossil groups were examined for biostratigraphic purposes: calcareous nannofossils, planktonic foraminifers, and dinoflagellate cysts. Benthic foraminifers were used to estimate palaeobathymetry and to establish preliminary palaeoenvironment and provenance interpretations. At Sites 1071 and 1072, the biostratigraphic resolution expressed by calcareous planktonic microfossils is limited by strong carbonate dissolution. Nannofossils provide useful zonations for the Pleistocene to Late Miocene. The stratigraphic use of planktonic foraminifers is restricted to the earliest PlioceneMiddle Miocene. Pleistocene benthic foraminiferal faunas vary from assemblages dominated almost exclusively by Elphidium excavatum to more diverse ones, reflecting changing palaeodepths or substrates related to glacial/interglacial cycles and/or changes in sediment input. Benthic foraminiferal species abundances indicate that palaeodepths in the Pleistocene fluctuated from inner neritic $(0-50 \mathrm{~m})$ to upper middle neritic $(\sim 50-65 \mathrm{~m})$. Pliocene-Miocene biofacies are characterized by Buliminella gracilis and Uvigerina junca, indicating middle neritic palaeodepths $(50-100 \mathrm{~m})$. Planktonic foraminifer assemblages can also be used to interpret glacial/interglacial depositional cycles. For example, high relative abundance of Neogloboquadrina pachyderma, particularly if dextrally coiled forms predominate, indicate colder conditions inferred to reflect glacial episodes whereas the occurrence of Globigerinoides ruber and Globorotalia truncatulinoides indicate full interglacial periods [2].

The sediment column was divided into three units on the basis of accessory components (glauconite, carbonate and pyrite nodules). Lithological units are similar at both sites [2]:

1. Lithological unit I is divided into three subunits. Subunits IA and IB are composed of Late Pleistocene sediments and contain clays, silty clays, and clayey silts interbedded with sandy silts, sandy clays, and sand. These subunits IA and IB are not easy to differentiate at Site 1072, so this interval is referred to as subunit IA/IB. Subunit IC contains Late Pliocene to Early Pleistocene sediments and is mainly composed of sandy sedi- 
Table I. Depth of seismic surfaces. A range of depth is also given (in parentheses) to reflect the uncertainty.

\begin{tabular}{ll}
\hline Seismic Surfaces & Depth (mbsf) \\
\hline pp3(s) & 57.5 \\
pp4(s) & $157(152.1-160.3)$ \\
pp5(s) & 254.2 \\
\hline
\end{tabular}

ments (sandy clays, sandy silts, and sand) at Site 1071, whereas at Site 1072 it comprises clayey silts and silty clays separated by silty sand.

2. Lithological unit II is divided into four subunits IIA to IID and contains Plio-Pleistocene to Upper Miocene sediments. These subunits are characterized by an alternation of silty clays, sandy clays, sandy silts, silty sands, and sand. Subunits IIC and IID were not drilled at Site 1072. Glauconitic pebbly sandstone was observed at the base of Subunit IIC at Site 1071 and of Subunit IIB at Site 1072 .

3. Lithological unit III, only recognized at Site 1071, is divided into two subunits and contains Upper Miocene to Middle Miocene sediments represented by silty clay, muddy sand, and sandy mud. This unit is mainly sandy.

The Miocene-Pleistocene succession is divisible into numerous unconformity-bounded sequences which represent the progressive infilling of a starved marine ramp, modulated by glacial-eustatic oscillations. At site $1072 \mathrm{~A}$, from $255 \mathrm{mbsf}$ to $0 \mathrm{mbsf}$, two surfaces corresponding to sequence boundaries are observed, pp3(s) and pp4(s) located respectively and approximately at 57.5 and $157 \mathrm{mbsf}$ (table I). The lower parts of associated sequences are comparatively more sandy and glauconitic and accumulated in shallower water (inner/upper middle neritic environment, 0-65 $\mathrm{m})$ than overlying finer grained sediments (middle neritic deposition, 50-100 m). In spite of marked offlap, each sequence is transgressive-dominated across virtually the entire shelf. The stratigraphic significance of $\mathrm{pp} 5(\mathrm{~s})$ is disputed, it may represent a Late Miocene flooding surface. It seems to be located approximately at $254.2 \mathrm{mbsf}$ that corresponds to the transition between Units IIA and IIB/C (table I) [2].

\section{METHODS}

Clay mineral associations of 205 samples (1071: 49 samples and 1072: 156 samples) have been studied using X-ray diffraction on oriented mounts. Deflocculation of clays was done by successive washing with distilled water after decarbonation of the crushed rock with $0.2 \mathrm{M} \mathrm{HCl}$. The clay fraction (less than $2 \mu \mathrm{m}$ particles) was separated by sedimentation and centrifugation $[6,21]$. X-ray diffractograms were obtained using a Philips PW 1730 diffractometer with $\mathrm{CuK}_{\alpha}$ radiations and $\mathrm{Ni}$ filter. A tube voltage of 40 $\mathrm{kV}$ and a tube current of $25 \mathrm{~mA}$ were utilized. Three $\mathrm{X}$-ray analyses were performed on each sample, after air-drying, ethylene-glycol solvation and heating at $490^{\circ} \mathrm{C}$ for two hours. The goniometer scanned from $2.5^{\circ}$ to $28.5^{\circ} 2 \theta$ for air-dried and glycol-solvated conditions and from $2.5^{\circ}$ to $14.5^{\circ} 2 \theta$ for heated conditions. The identification of clay minerals was made according to the position of the (001) basal reflections on the three X-ray diagrams $[6,34,40]$. Semi-quantitative estimations are based on the intensity and on the area of the main diffraction peak of each mineral [21].

\section{RESULTS}

The clay mineral assemblages identified are composed of chlorite $(0-45 \%)$, illite $(23-97 \%)$, kaolinite $(0-$ $62 \%$ ), vermiculite $(0-15 \%)$, smectite $(0-22 \%)$, and randomly interstratified minerals (mixed-layers, 0 $22 \%$ ) including illite/vermiculite and chlorite/vermiculite (figures 2 and 3). Variable amounts of quartz, feldspars, amphibole, and gibbsite are associated with the clay minerals in the $<2 \mu$ m sedimentary fraction.

At Site 1072, three successive clay mineralogical zones (CMZ 1 to 3 ) are identified according to the appearance or disappearance of clay minerals and their relative percentages (figure 2). At Site 1071, two successive CMZ (CMZ 0 and 1) are identified in the studied interval (figure 4). Data will be discussed primarily from 1072, which is the more complete site.

\section{- CMZ 1: Late Miocene (254.75-152.13 mbsf at site $1072 ; 175.40-134.40$ mbsf at site 1071$)$}

CMZ 1 coincides with lithological subunit IIA. The base of this subunit is characterized by glauconitic silty sand at site 1072 [2]. Vermiculite is present (average $10 \%$ ) with chlorite (average $4 \%$ ) in low proportions (figures 2 and 4). Percentages of illite, kaolinite and mixed-layers are relatively constant. 


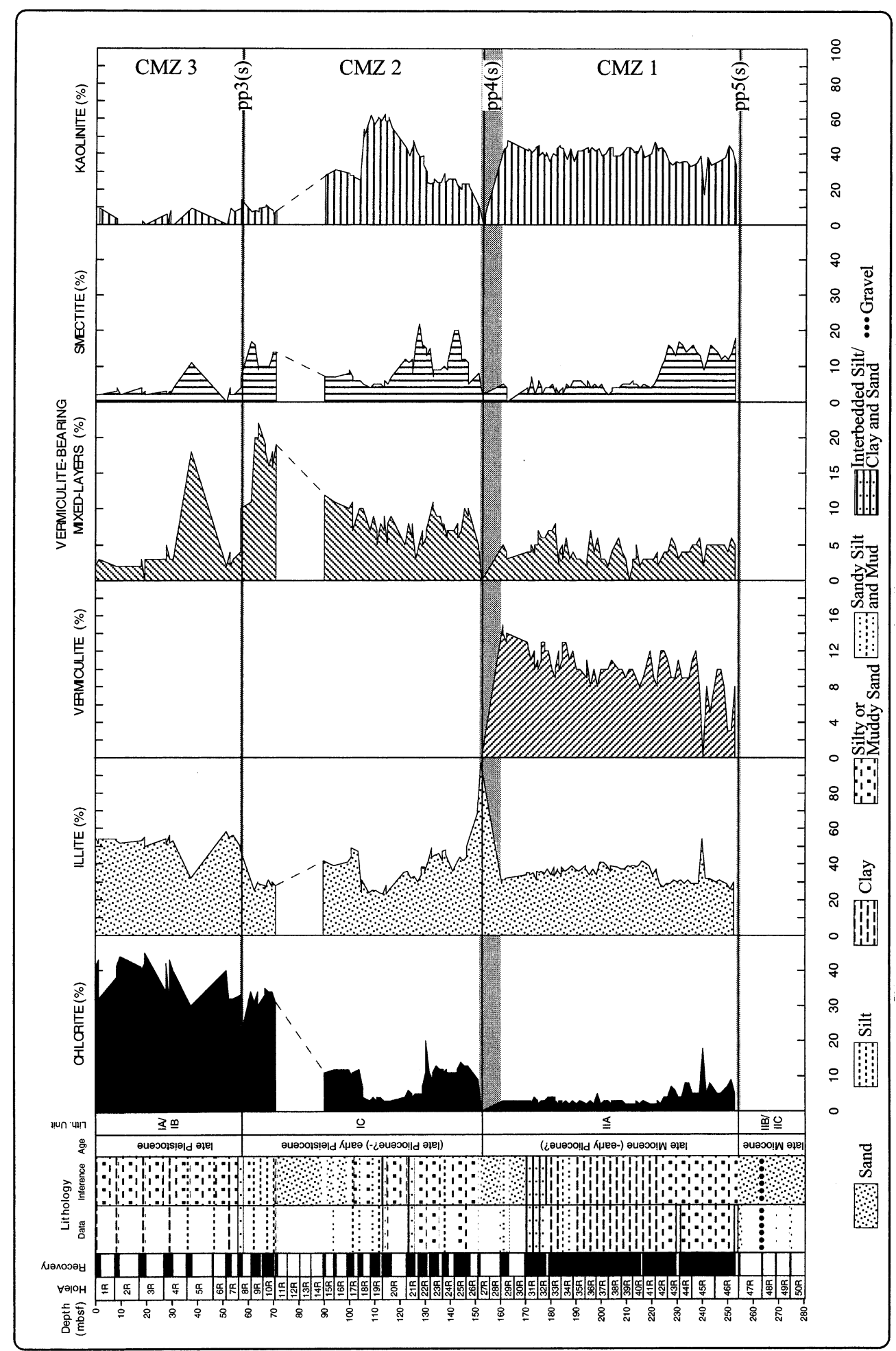

Figure 2. Lithology and clay mineralogy of sediments drilled at ODP site 1072 . 
Smectite and chlorite show higher proportions at the base than at the top (figure 2).

\section{- CMZ 2: Late Pliocene-Early Pleistocene (152.13-} 57.5 mbsf, site 1072)

CMZ 2 coincides with lithological unit IC. It is characterized by the disappearance of vermiculite (figures 2 and 3). The proportions of chlorite and mixed-layers are higher than in CMZ 1. At the base of the zone, a strong reflection at $10 \AA$ (97\%) corresponds to glauconite. Percentages of kaolinite increase from the base to the middle part of this zone and then decrease towards the top (figure 2). The proportions of mixed-layers (especially I/V) are higher in the interval covering cores 11 to 9 (figure 2).

\section{- CMZ 3: Late Pleistocene (57.5-0 mbsf, site 1072)}

CMZ 3 coincides with lithological unit IA/B. It is
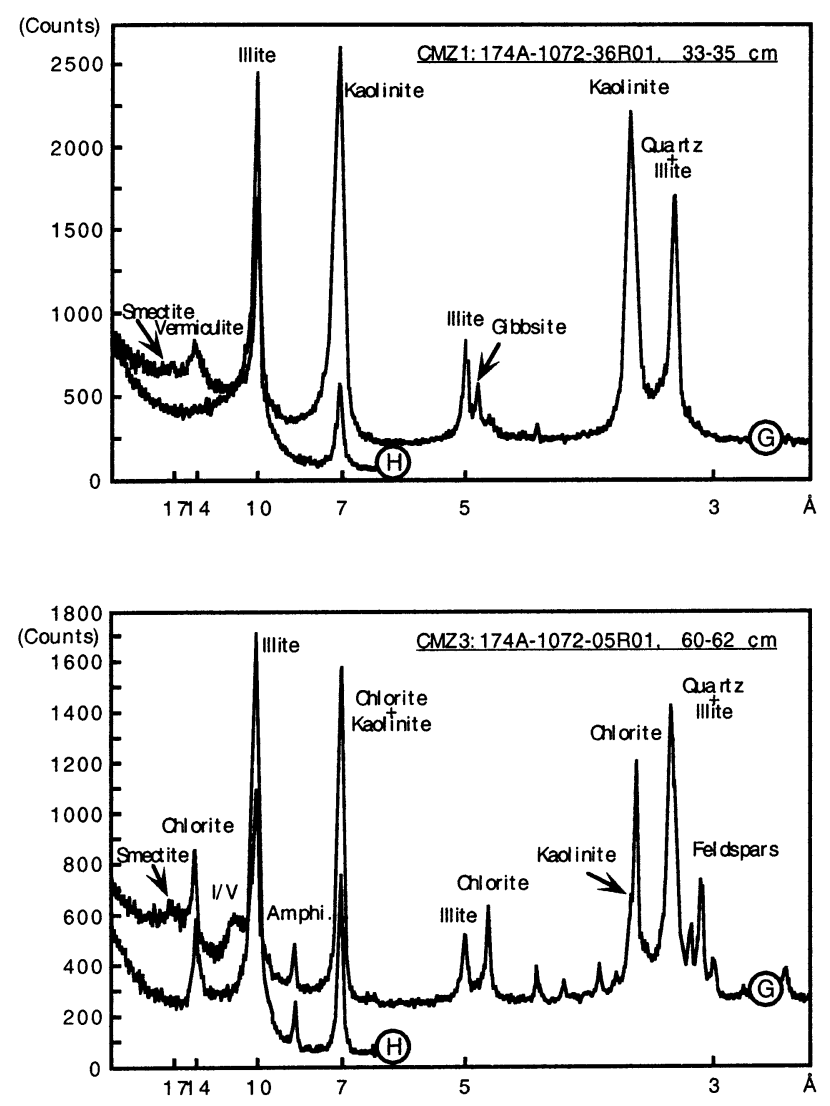

characterized by the highest percentages of primary detrital clay minerals such as chlorite and illite, that are associated with low amounts of smectite, kaolinite, and random mixed-layers (figures 2 and 3). However, an interval with higher proportions of smectite, kaolinite and mixed-layers, and lower percentages of illite and chlorite occurs in core 5R (figure 2). On Xray diffractograms accessory detrital minerals such as amphibole and feldspars are also identified (figure 3).

An additional, older, clay mineralogical zone (CMZ 0) is recognized at Site 1071. It encompasses subunits IIIa to IIB (Middle to Late Miocene). Sediments contain a high proportion of sand [2], and the clay sampling resolution is poor. This $\mathrm{CMZ}$ is characterized by higher percentages of chlorite and smectite than in the above CMZ, and vermiculite is absent (figure 4).

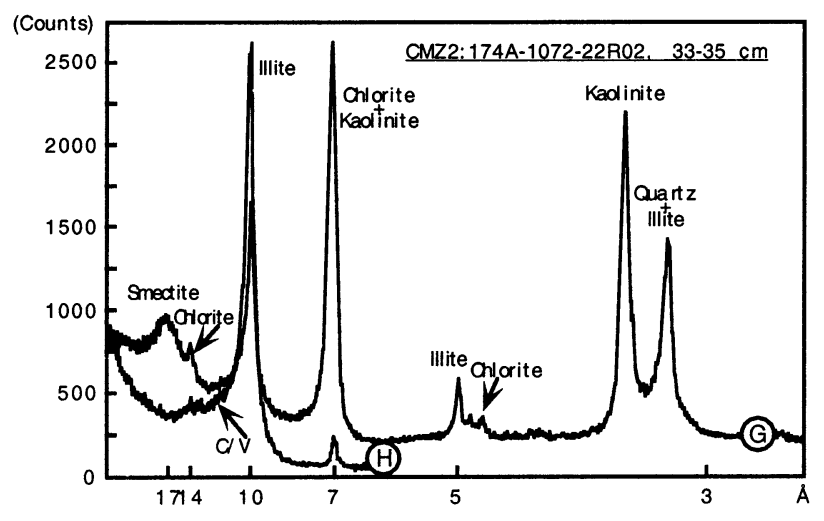

Figure 3. Typical X-ray diffractograms (glycolated and heated) from each Clay Mineral Zone (CMZ). I/V = illite/vermiculite mixed-layers; $\mathrm{C} / \mathrm{V}=$ chlorite/vermiculite mixed-layers; Amphi. = Amphibole. 


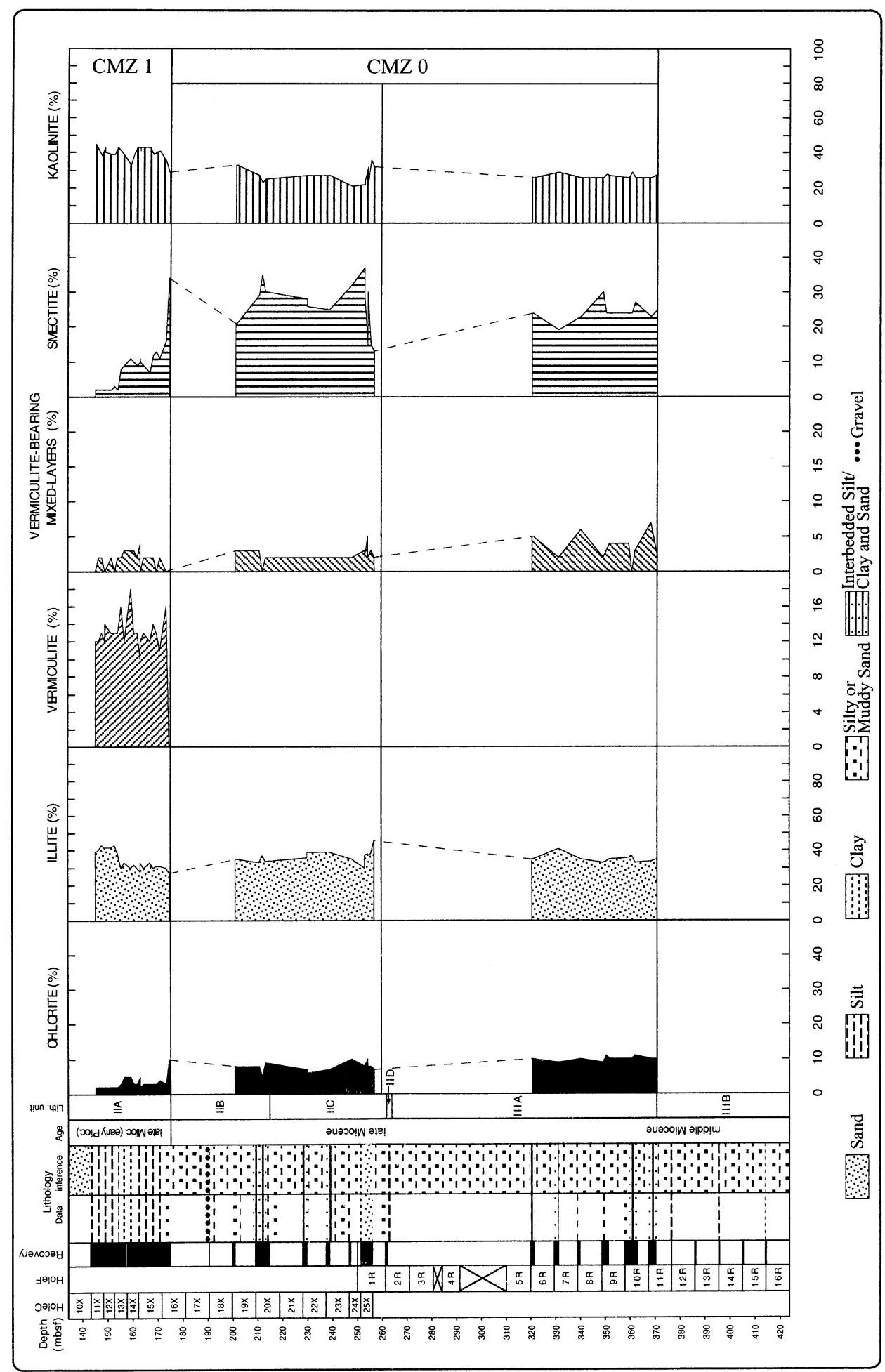

Figure 4. Lithology and clay mineralogy of sediment drilled at ODP site 1071. 


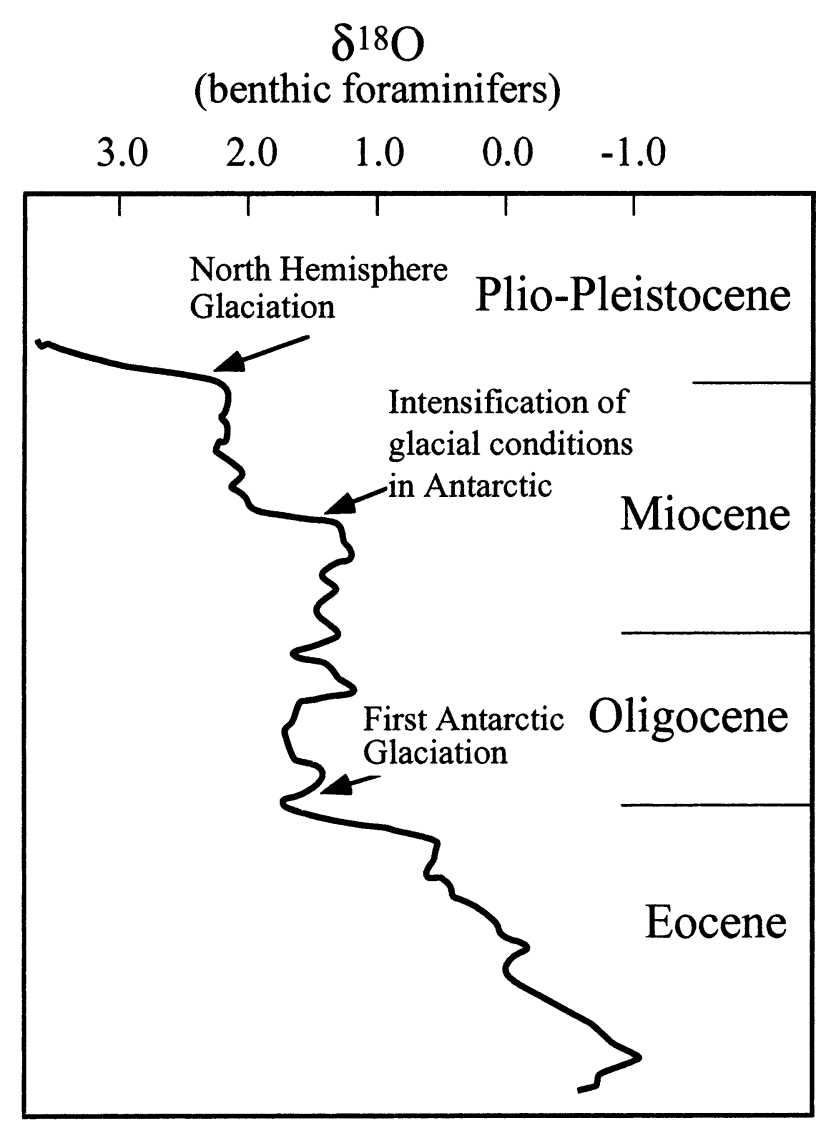

Figure 5. Composite benthic foraminiferal oxygen isotope record for Atlantic DSDP sites corrected to Cibicidoides and reported to Pee Dee Belemnite standard (PDB). Modified from [28].

\section{DISCUSSION}

\subsection{Origins of clay minerals}

Chlorite and illite constitute the major part of clay assemblages in recent sediments of the Northwest Atlantic Ocean $[4,11,19]$. These minerals result from mechanical to low chemical weathering of crystalline rocks cropping out on continental areas, and their amounts increase during glacial stages [8]. Chlorite is more easily altered by chemical weathering. Together with illite, it is typical of high-latitude sediments deposited during glacial periods [4, 7]. By contrast, kaolinite dominantly proceeds from more hydrolyzing climates (warmer and more humid) inducing active weathering in well-drained continental environments from lower latitude areas [8, 33]. Smec- tite has a more variable origin. This mineral is either detrital, authigenic or an alteration product of volcanic material, but the first origin predominates in Cenozoic Atlantic open-sea sediments [8]. The occurrence of vermiculite dominantly expresses the weathering and transformation of a $10 \AA$ mica (biotite or muscovite) $[1,25,33,36,41,42]$. The transformation of biotite into vermiculite often requires a change from a trioctahedral to a dioctahedral structure. This phenomenon has been described for Fe-rich species by [13]. The loss of octahedral cations and their replacement by $\mathrm{Al}$, especially mobile at low $\mathrm{pH}$ [15], occurs during weathering in an acidic soil environment and allows the formation of aluminous, dioctahedral vermiculite. The occurrence of vermiculite-bearing mixed-layers is often observed and may be explained by the weathering of primary aluminosilicates such as chlorite [1]. Experimental vermiculitization of chlorite has been obtained by a thermal dehydroxylation followed by an acid dissolution of hydroxide sheets, often via an intermediate chlorite/vermiculite stage [23, 44].

\subsection{Cenozoic climatic evolution}

The climatic record of the last 70 million years is dominated by the transition between the warm Cretaceous and the widespread glaciation of the Pleistocene. This transition is punctuated by events. Some of the more significant and well-documented events include the Eocene-Oligocene boundary event characterized by the first significant ice-rafted deposition adjacent to Antarctica during the Oligocene in response to the first Antarctic glaciation, a global cooling during the Middle Miocene (between 15 to $13 \mathrm{Ma}$ ) corresponding to an intensification of glacial conditions in Antarctica, and northern hemisphere glaciation between ten and three million years ago [3, 14, 28]. During the Miocene, two periods of Antarctic ice-sheet growth are observed, the first one during the Middle Miocene (formation of the east Antarctic ice-sheet) and the second one during the Late Miocene (formation of the West Antarctic ice-sheet) [26]. The benthic foraminiferal Tertiary $\delta^{18} \mathrm{O}$ records from the Atlantic show that oxygen isotope values generally increase from the Eocene to Recent (figure 5). The $\delta^{18} \mathrm{O}$ increases result partly from increases in ice volume. Changes of $\delta^{18} \mathrm{O}$ values from Oligocene to Recent represent ice growth and decay [28]. 


\subsection{Palaeoclimatic interpretations}

\section{- CMZ 0: Middle Miocene-Late Miocene}

Clay mineral data of the Middle to Late Miocene CMZ0 at Site 1071 are of poor quality due to the paucity of the clay fraction in the sandy lithofacies typical of a proximal, nearshore depositional environment and to the poor recovery. The proximity of the coast is corroborated by the relatively high percentages of kaolinite which, together with chlorite, settles preferentially in the ocean close to continental detrital sources because kaolinite and chlorite have the coarsest crystal plates (figure 4) [25].

\section{- CMZ 1: Late Miocene}

The abundance of illite (figure 2) indicates the active erosion of the Appalachian mountain range, which is also supported by the occurrence of terrestrial rather than marine organic matter associated with clastic debris eroded from older rocks exposed on the continent [2]. The Appalachian Highlands were the main terrigenous source terrain, and the ancient Delaware and Hudson Rivers constitute the main sediment dispersal routes [38]. Surprisingly, the amounts of chlorite are very low relative to illite (figure 2), suggesting that hydrolyzing conditions were too strong to allow the preservation of this mineral. The increased proportions of illite are consistent with global cooling starting in the Early Oligocene [8, 28], but the high percentages of kaolinite are more unusual. According to the climatic context, it is difficult to consider that kaolinite was reworked only from Oligocene to Middle Miocene soils. It is likely that kaolinite was reworked from older sedimentary rocks eroded together with crystalline rocks from the Appalachians, or from kaolinite-bearing soils developed during Eocene, Paleocene, and even Late Cretaceous [16, 17, 19, 25]. Late Cretaceous to early Cenozoic hydrolysing climates favoured the formation of kaolinite on the eastern North American continent [3, 19]. For example, in southwestern New Jersey, Late Paleocene deposits contain a large proportion of kaolinite $[16,17]$. Therefore, it is likely that kaolinite was mostly eroded from pre-Oligocene weathering profiles and supplied to the Atlantic Ocean by rivers crossing the Appalachians. But abundance of kaolinite at mid and high latitudes in the North and South Atlantic can also be linked to enhanced humidity that occurs at a period when the development of the west
Antarctic ice-sheet followed an increase of polar humidity [43].

\section{- CMZ 2: Late Pliocene-Early Pleistocene}

The disappearance of vermiculite and the increase in abundance of mixed-layers (figure 2) indicate less hydrolysing conditions and the decrease of chemical weathering of exposed soils and rocks, due to climatic cooling. The transformation of biotite into vermiculite is not complete and is limited to random illite/ vermiculite mixed-layers. As shown by [5] and [49], increasing amounts of mixed-layers in the North Atlantic Ocean are able to reflect interglacial weathering conditions on exposed land masses. The higher proportions of mixed-layers from cores 11 to 9 at Site 1072 relative to surrounding sediments is therefore attributed to interglacial conditions. This is connfirmed by the occurrence of Globorotalia truncatulinoides which is a planktonic foraminera species characteristic of interglacial periods [2].

Less hydrolyzing conditions are also reflected by the occurrence of higher proportions of chlorite than in CMZ 1. Climatic models predicted a general decline in precipitation rates through the Cenozoic for the Appalachians [3]. Together with a lower average temperature, these climatic conditions on land would have favoured the preservation of chlorite and illite, and disfavoured the formation of kaolinite. However, the interval between 130.03 and 104.52 mbsf is characterized by higher percentages of kaolinite and lower percentages of chlorite and illite (figure 2). It can be attributed to more hydrolysing conditions in response to warmer and more humid climates and resulting in the decrease of clay minerals formed by mechanical weathering. Therefore this interval can express a deposition developed under interglacial conditions.

\section{- CMZ 3: Late Pleistocene}

Chlorite and illite constitute the dominant clay minerals at the expense of both smectite and kaolinite (figure 2). From Baffin Bay in the north to lower latitudes, a similar increase of chlorite and illite is observed in Pleistocene sediments of the North Atlantic Ocean [8, 19, 47]. As at Sites 902, 903 and 905, and in the Atlantic City Borehole (figure 1) [11, 48, 49], these minerals reflect a drastic change of detrital sources. The common occurrence of amphiboles and feldspars (figure 3) and a change of quartz grains shape [24] confirm such an hypothesis. The feldspar- 
rich sediments are derived from Precambrian and Paleozoic rocks in which weathering has been mainly mechanical [32]. Illite and chlorite are primarily inherited from the North American crystalline basement and transported by ice-sheets and marine currents $[9,12,20,47]$. Investigations of mineralogical composition of sand-sized sediment from the US middle Atlantic shelf show the dominant influence of the Hudson River from New York to Cape Hatteras latitudes [10, 22, 31]. The Hudson River drained glaciated regions to the north [38, 39] and supplied terrigenous material to the coastal plain, outer shelf and upper slope areas off New Jersey [45]. This clay assemblage is characteristic of the development of the Arctic polar ice-sheet.

However, in core 5, the lower percentages of primary clay minerals (illite and chlorite) and the higher proportions of smectite and mixed-layers (figure 2) may correspond to interglacial conditions both favouring the formation of these clay minerals, and disfavouring the preservation of detrital chlorite.

\subsection{Comparisons with onshore and offshore sites (Atlantic City Borehole, ODP 1072, 903, and 905)}

On the continental rise at site 905 , sedimentation was strongly affected by gravity-driven processes and at Atlantic City borehole on the coastal plain, Late Miocene and Pliocene sediments are missing [11, 48]. It is therefore very difficult to envisage stratigraphic correlations between Site 1072 and both Atlantic City borehole and Site 905. In all sites, Pleistocene clay sedimentation is characterized by high percentages of so-called primary minerals (chlorite and illite), low proportions of smectite and kaolinite, and the occurrence of mixed-layers such as I/V [11, 48].

Correlation between shelf- and slope-deposited sediments deduced from biostratigraphic data (nannofossils, planktonic and benthic foraminifers) [2, 35] shows a Miocene to Pleistocene increase of primary minerals percentages (chlorite and illite) and a concomitant decrease of kaolinite and smectite in relation with the global cooling [11]. However, the sediments deposited during the Late Miocene on the slope (site 903) contain no vermiculite. There are some possible explanations. First, the Late Miocene stratigraphic interval encountered at both locations is perhaps not of exactly the same age. Second, sediments on the shelf are sandier than those on the slope and could therefore more likely include vermiculite that often comprises rather large particles. As far as early Pleistocene is concerned, this interval on the shelf may correspond to the top of the stratigraphic column at Site 903 on the continental slope since the clay assemblage is similar at both locations, with higher percentages of primary minerals (chlorite and illite) and lower proportions of smectite and kaolinite, and the occurrence of mixed-layers such as $\mathrm{I} / \mathrm{V}$ [11].

\section{CONCLUSIONS}

Miocene to Pleistocene sediments were drilled on the outer New Jersey shelf during ODP Leg 174A. Clay mineral assemblages were determined to study the origin and sources of these sediments. The Miocene to Pleistocene sedimentation is controlled mainly by the decrease of hydrolyzing conditions in relation with northern hemisphere ice-sheet growth. From base to top of the lithological column, the clay mineral sedimentation is first controlled by chemical, hydrolysing conditions allowing the formation of vermiculite and fairly abundant kaolinite during the Late Miocene. The Late Pliocene-Early Pleistocene expresses the transition to more glacial conditions with an increase of mixed-layers at the expense of vermiculite which disappears. An interglacial interval is revealed by higher proportions of mixed-layers (especially I/V) and lower percentages of primary detrital minerals (illite and chlorite). During the Late Pleistocene, the sedimentation is characterized by an increase of primary minerals (chlorite and illite) and a decrease of kaolinite, smectite and mixed-layers in response to the development of the northern hemisphere ice caps and the mechanical erosion of crystalline basement.

The trend observed in the composition of clay assemblages is relatively similar in the coastal plain (Atlantic City borehole), on the continental slope (Site 903) and rise (Site 905). The climatic variations seem to have dominantly controlled the clay mineralogical fluctuations with the increase of clay minerals issued from mechanical erosion and decrease of clay minerals formed by chemical weathering. The same clay mineral species, except vermiculite, and similar trends 
in the vertical evolution of percentages are observed at all sites. The succession of clay assemblages illustrates that the decreasing hydrolyzing climates favouring increased physical weathering.

The next step of investigation requires a higher resolution study of clay mineralogy associated with a high resolution shore-base study of biostratigraphy, which would provide a detailed record of glacial/interglacial alternations in the Pleistocene section at site 1072, as was done for Pleistocene section at Site 902 (Leg 150) [49].

\section{Acknowledgements}

The author thanks the members of the ODP Leg 174A scientific party for their helpful comments on the initial version of the manuscript, and P. Récourt and D. Malengros for their assistance with XRD work. She also thanks H. Chamley, V. Bout-Roumazeilles and J.F. Deconinck for their helpful comments. This study was supported by INSU grant, program "Géosciences Marines" contribution no. 97N51/0730.

\section{REFERENCES}

[1] April R.H., Hluchy M.M., Newton R.M., The nature of vermiculite in Adirondack soils and till, Clays and Clay Min. 34 (1986) 549-556.

[2] Austin J.A., Christie-Blick N. et al., Proc. ODP, Init. Repts., 174A: College Station, TX (Ocean Drilling Program), 1998, pp. 324.

[3] Barron E.J., Climate variations and the Appalachians from the Late Paleozoic to the Present: results from model simulations, Geomorphology 2 (1989) 99-118.

[4] Biscaye P.E., Mineralogy and sedimentation of recent deepsea clays in the Atlantic Ocean and adjacent seas and oceans, Geol. Soc. Am. Bull. 76 (1965) 803-832.

[5] Bout-Roumazeilles V., Relations entre variabilités minéralogiques et climatiques enregistrées dans les sédiments de l'Atlantique Nord pendant les huit derniers stades glaciairesinterglaciaires, thèse univ. Lille-I, 1995, p. 280.

[6] Brown G., Brindley G.W., X-ray diffraction procedures for clay mineral identification, in: Brindley G.W., Brown G. (Eds.), Crystal Structures of Clay Minerals and Their X-ray Identification, vol. 5, Mineral Soc. Monogr., London, 1980, pp. 305-359.

[7] Chamley H., North-Atlantic clay sedimentation and palaeoenvironment since the Late Jurassic, Deep Drilling results in the Atlantic ocean: continental margins and palaeoenvironment ; in : Talwani, M., Hay W., Ryan W.B.F. (Ed.), Maurice Ewing ser. 3, 1979, pp. 342-361.
[8] Chamley H., Clay Sedimentology, Springer Verlag, Berlin, 1989, p. 623.

[9] Cremer M., Maillet N., Latouche C., Analysis of sedimentary facies and clay mineralogy of the Neogene-Quaternary sediments in ODP Site 646, Labrador Sea; in: Srivastava, S.P., Arthur M., Clement B. et al. (Ed.), Proc. ODP, Sci. Results, 105: College Station, Texas (Ocean Drilling Program), 1989, pp. $71-81$.

[10] Darby D.A., Evidence for the Hudson River as the dominant source of sand on the US Atlantic Shelf, Nature 346 (1990) $828-831$.

[11] Deconinck J.F., Vanderaveroet P., Eocene to Pleistocene clay mineral sedimentation off New Jersey, Western North Atlantic (ODP, Leg 150, Sites 903 and 905), in: Mountain G.S., Miller K.G., Blum P., Poag C.W., Twichell D.C. (Ed.), Proc. ODP, Sci. Results, 150: College Station, TX (Ocean Drilling Program), 1996, pp. 147-170.

[12] Dunn D.A., Patrick D.M., Cooley U. Jr., Cenozoic clay mineralogy of Sites 604 and 605, New Jersey Transect, DeepSea Drilling Project Leg 93, in: van Hinte, J.E., Wise S.W. Jr., et al. (Ed.), Init. Repts, DSDP, 93: Washington (U.S. Govt. Printing Office), 1987, pp. 1023-1037.

[13] Farmer V.C, Russel J.D., McHardy W.J., Newman A.C.D., Ahlrichs J.L., Rimsaite J.Y.H., Evidence for loss of protons and octahedral iron from oxidized biotites and vermiculites, Mineral. Mag. 38 (1971) 121-137.

[14] Frakes L.A., Climates throughout geologic time, Elsevier, New York, NY, 1979, p. 310.

[15] Garrels R.M., Christ C.L., Solutions, Minerals, and Equilibria, Freeman, Cooper and Co., San Francisco, 1965, p. 450.

[16] Gibson T.G., Bybell L.M., Owens J.P., Latest Paleocene lithologic and biotic events in neritic deposits from southwestern New Jersey, Paleoceanography 8 (1993) 495-514.

[17] Gibson T.G., Bybell L.M., Owens J.P., Mason D.B., McCar$\tan$ L., Snow J.N., Climatic and stratigraphic implications of clay mineral changes in: Paleocene/Eocene boundary strataEastern United States, Geol. Soc. Am. Abst. Prog. 26 (1994) 15 .

[18] Grow J.A., Sheridan R.E., U.S. Atlantic continental margin; a typical Atlantic-type or passive continental margin, in: Sheridan R.E., Grow J.A. (Ed.), The Geology of North America (Vol. I-2): The Atlantic Continental Margin. Geol. Soc. Am. 1988, pp. 1-7.

[19] Hathaway J.C., Regional clay mineral facies in estuaries and continental margin of the United States East Coast, Geol. Soc. Am. Mem. 133 (1972) 293-316.

[20] Hathaway J.C., Mineralogic evidence of Quaternary currents regimes on the Atlantic Continental Margin, Conference on Continental Margin Mass Wasting and Pleistocene Sea-Level Changes, U.S. Geological Survey, 5 (1980) 302-330.

[21] Holtzapffel T., Les minéraux argileux, préparation, analyse diffractométrique et détermination, Soc. Géol. Nord, Publ. $\mathrm{n}^{\circ} 12,1985$, p. 136.

[22] Kelling G., Sheng H., Stanley D.J., Mineralogical composition of sand-sized sediment on the outer margin off the 
Mid-Atlantic states: assessment of the influence of the ancestral Hudson and other fluvial systems, Geol. Soc. Am. Bull. 86 (1975) 853-862.

[23] Makumbi L., Herbillon A.J., Vermiculitisation expérimentale d'une chlorite, Bull. Groupe Franç. Argiles 24 (1972) 153164.

[24] Mazzullo J., Sources of Miocene, Pliocene, and Pleistocene siliciclastic sediments in Unit I, Sites 612 and 613, in: Poag C.W., et al. (Ed.), Inits. Repts. DSDP, 95: Washington (U.S. Govt. Printing Office), 1987, pp. 581-585.

[25] McCartan L., Geology and Paleontology of the Haynesville Cores Northeastern Virginia coastal plain, U.S. Geol. Surv. Prof. Pap. 1489 (1988).

[26] Mercer J.H., Glacial development and temperature trends in the Antarctic and in South America, in: Van Zinderen Bakker E.M. (Ed.), Antarctic glacial history and World paleoenvironments, Balkema, Rotterdam, 1978, pp. 73-94.

[27] Miller K.G., Browning J.V., Liu C., Sugarman P.J., Kent D.V., Van Fossen M., Queen D., Goss M., Gwynn D., Mullikin L., Feigenson M.D., Aubry M.P., Burckle L.D., Atlantic City Report, Proc. ODP, Init. Repts., 150X: College Station, TX (Ocean Drilling Program), 1994, p. 59.

[28] Miller K.G., Fairbanks R.G., Mountain G.S., Tertiary oxygen isotope synthesis, sea level history, and continental margin erosion, Paleoceanography 2 (1987) 1-19.

[29] Miller K.G., Sugarman P.J., Correlating Miocene sequences in onshore New Jersey boreholes (ODP Leg 150X) with global (18O and Maryland outcrops, Geology 23 (1995) 747-750.

[30] Miller K.G. et al., Proc. ODP, Init. Repts., 150X (Suppl.): College Station, TX (Ocean Drilling Program), 1996, p. 28.

[31] Milliman J.D., Jiezao Z., Anchun L., Ewing J.I., Late Quaternary sedimentation on the outer and middle New Jersey continental shelf: result of two local deglaciations?, J. Geol. 98 (1990) 966-976

[32] Milliman J.D., Pilkey O.H., Ross D.A., Sediments of the Continental Margin off the Eastern United States, Geol. Soc. Am. Bull. 83 (1972) 1315-1334.

[33] Millot G., Geology of Clays, Springer Verlag, New York, $1970,425 \mathrm{p}$.

[34] Moore D.M., Reynolds R.C., X-ray diffraction and the identification and analysis of clay minerals, Oxford Univ. Press, Oxford, 1989

[35] Mountain G.S., Miller K.G., Blum P. et al., Proc. ODP, Init. Repts., 150: College Station, TX (Ocean Drilling Program), 1994, p. 885.

[36] Petersen L., Rasmussen K., Mineralogical composition of the clay fraction of the two fluvio-glacial sediments from East Greenland, Clay Min. 15 (1980) 135-145.

[37] Poag C.W., Depositional history and stratigraphic reference section for central Baltimore canyon Trough, in: Poag C.W.
(Ed.), Geologic Evolution of the United States Atlantic Margin, Van Nostrand Reinhold, New York, 1985, pp. 217263.

[38] Poag C.W., U.S. Middle Atlantic Continental Rise: Provenance, dispersal, and deposition of Jurassic to Quaternary sediments, in: Poag C.W., de Graciansky P.C. (Eds.), Geologic Evolution of Atlantic Continental Rises, Van Nostrand Reinhold, New York, 1992, pp. 100-156.

[39] Poag C.W., Sevon W.D., A record of Appalachian denudation in postrift Mesozoic and Cenozoic sedimentary deposits of the U.S. middle Atlantic margin, Geomorphology 2 (1989) $119-157$.

[40] Reynolds R.C., Interstratified clay minerals, in: Brindley G.W., Brown G. (Ed.), Crystal Structures of Clay Minerals and Their X-ray Identification, London, Mineral Soc. Monogr. 5 (1980) 249-303.

[41] Rich C.I., Hydroxy interlayers in expansible layers silicates, Clays and Clay Min. 16 (1968) 15-30.

[42] Rich C.I., Cook M.G., Formation of dioctahedral vermiculite in Virginia soils, Clays and Clay Min. 10 (1963) 96-106.

[43] Robert C., Chamley H., Cenozoic evolution of continental humidity and paleoenvironment, deduced from the kaolinite content of oceanic sediments, Pal. Pal. Pal. 60 (1987) 171-187.

[44] Ross G.J., Kodoma H., Experimental transformation of a chlorite into a vermiculite, Clays Clay Min. 22 (1974) 205211.

[45] Saito Y., Grain-size and sediment-color variations of Pleistocene slope sediments off New Jersey, in: Mountain G.S., Mille K.G., Blum P., Poag C.W., Twichell D.C. (Ed.), Proc. ODP, Sci. Results, 150: College Station, TX (Ocean Drilling Program), 1996, pp. 229-239.

[46] Sheridan R.E., Gradstein F.M. et al., Init. Repts. DSDP, 76: Washington (U.S. Govt. Printing Office), 1983, 947 p.

[47] Thiebault F., Cremer M., Debrabant P., Foulon J., Nielsen O.B., Zimmerman H., Analysis of sedimentary facies, clay mineralogy, and geochemistry of the Neogene-Quaternary sediments in Site 645, Baffin Bay; in: Srivastava S.P., Arthur M., Clement B. et al. (Eds), Proc. ODP, Sci. Results, 105: College Station, Texas (Ocean Drilling Program), 1989, pp. 83-100.

[48] Vanderaveroet P., Deconinck J.F, Clay mineralogy of Cenozoic sediments of the Atlantic City Borehole, New Jersey, in: Miller K.G. Snyder S.W. (Eds.), Proc. ODP, Sci. Results, 150X: College Station, TX (Ocean Drilling Program), 1997, pp. $49-57$.

[49] Vanderaveroet P., Averbuch O., Deconinck J.F., Chamley H., A Record of Glacial/Interglacial Cycles in Pleistocene Sediments off New Jersey Expressed by Clay Minerals, Grain-Size and Magnetic Susceptibility Data, Mar. Geol. 159 (1999) 79-92. 